\title{
Study on the Influence of American Anti-dumping towards China on China's Export
}

\author{
Lai Huaying \\ School of Economics, Shanghai University, Shanghai, China
}

Keywords: anti-dumping; trade effect; anti-dumping duty; affirmative verdict

\begin{abstract}
Based on 1995-2014 HS6-bit encoded data of American anti-dumping cases, this paper studies the influence of American anti-dumping towards China on China's export. The sample period of export data is from 1994 to 2017, and counted the amount of exports for products involved in American anti-dumping cases before and after the anti-dumping verdict for five consecutive years. The empirical analysis shows that, the American anti-dumping investigation has an influence on China's export, among them, affirmative verdict and the imposition of anti-dumping duties have negative effects on China's export to the year of the verdict and in the first year after the verdict, especially the most seriously to the year of the verdict, and this negative effects in the following years gradually eased. On the other hand, negative verdict has negative effects to the year of the verdict, however, not significantly effects on the amount of China's export to America in the first and second year after the verdict. The anti-dumping investigation is becoming increasingly fierce, the American anti-dumping brings damage on China's export and major loss on benefits of export enterprise and economic development in China, Chinese government and enterprises should take measures actively to decrease and decline the disadvantageous influence of American anti-dumping on China's export.
\end{abstract}

\section{Introduction}

Since the establishment of Sino-US diplomatic relations, the development of economic and trade cooperation grows rapidly, and China's economy has developed rapidly since joining the WTO in 2001, GDP growing from 11086.3 billion in 2001 to 82712.2 billion in 2017. On the contrary, since the financial crisis in 2008, the world economy has been in recession, the economy of western developed countries grows in slow speed, even in recession, the U.S. economy is cooling, the Fed (the Federal Reserve) stimulate the economy by means of the reduction of interest; the Brexit vote of Britain in 2016 leads to the general decline of stock market of Europe, Asia, America; whereas, China's economy remains high increase, the scale of foreign trade expanding continuously, and there remains relatively large favorable balance of trade in foreign trade for a long period of time. In view of this, trade protectionism in Europe, the United States and other developed countries have risen frequently, trade frictions have occurred frequently, and China has deeply suffered from it. According to the WTO anti-dumping statistics, the total number of anti-dumping investigations conducted on China from January 1, 1995 to December 31, 2016 reached 1217, accounting for $23.02 \%$ of 5286 totally in the world, among them, the United States has initiated 141 anti-dumping cases against China, accounting for $23.27 \%$ of the total 606 anti-dumping cases filed by the United States, far exceeding cases against other countries in the same period (46 against Korea and 41 against Japan). China is the country with the largest number of anti-dumping cases from the United States. Therefore, it is very necessary at this stage to study the impact on China's export from the perspective of U.S. anti-dumping against China, with important research and practical value.

\section{Literature Review}

Since the reform and opening-up, China's foreign trade develops rapidly and becomes a big trade exporter in the world, however, Chinese enterprises frequently suffer from anti-dumping investigations from Europe, America and other countries in the process of development. Studies on 
anti-dumping has become a hot issue in the field of international trade and attracts many scholars.

Based on the theoretical analysis, domestic scholars, Yang Shihui, Wang Hongling, Shu Yanyan (2001) establish a dynamic game model of implementing party, dumping party and non-dumping party, discuss the impact of anti-dumping policies on international competition and the incentive mechanism in the host country, and preliminarily explore the strategies to deal with anti-dumping on export; Yang Zhansheng, Ma Haiyan, Zhong Changbiao (2014) study on the causes of U.S. anti-dumping towards China by using two counts of negative model, believes that there is negative correlation between the fluctuations on American industrial production and American anti-dumping charges towards China, in other words, if the American domestic economy is more prosperous, the number of anti-dumping charges towards China is smaller, otherwise it will increase; foreign scholar, Khatibi (2009) analyzes the trade diversion effect of anti-dumping, which is that anti-dumping measures not only promote trace of exporter to divert to the third country from the implementing party, but also divert the import of implementing party to other export countries without anti-dumping implemented; Vandenbussche and Zanardi (2010) study the impact of anti-dumping on the total amount of import with gravity model based on annual observations (1980-2000), finds that anti-dumping reduces imports and has a strong trade destruction effect.

From the impacting effect of anti-dumping on export, domestic scholars, Xie Jianguo, Huang Qiuyue (2014) take cases data of American anti-dumping towards China from 1991 to 2008, obtain export data in consecutive seven years of HS8-bit encoded data of American anti-dumping cases, and the results of empirical analysis show that American anti-dumping towards China has an influence on China's export, however, there is short-term characteristics in this influence; Tang Yihong and Zhang Pengyang (2016) mainly select cases of anti-dumping towards China in 2009 as research object, analyze the impact of anti-dumping on export scale and export price and its dynamic changes by the difference-in-difference model. The results show that anti-dumping has an inhibiting effects on export scale but promoting effects on export price in short time, which are all not obvious in the long period of time. Foreign scholar, Besedeš and Prusa (2013) find out that exporters exit from the market due to anti-dumping investigation, and anti-dumping actions increase the hazard rate up to 50\%; Avsar (2013) believes that export enterprises are forced to increase significantly the export price of investigated products to decrease the dumping margin of probable verdict because of anti-dumping activities.

From the trade effect of anti-dumping, domestic scholars, Wang Jingyi (2014) takes anti-dumping investigation on photovoltaic products of China as an example, finds that anti-dumping investigation has an obvious and far-reaching trade destruction effect on involved products with strong trade diversion effect, which brings obvious trade depression effect and trade deflection effect; Wang Xiaosong, Zhai Guangyu, and Lin Faqin (2015) study the trade-restrictive effect of foreign anti-dumping towards China on China's export with anti-dumping data of China with 24 foreign trading partners from 1992 to 2010, finds that anti-dumping of trading partners has significantly inhibited China's export; foreign scholar, Soonchan (2009) discusses impact of China's anti-dumping on trade, conducts empirical analysis with cases of China's anti-dumping towards foreign countries from 1997 to 2004 as sample, finds the trade depression effect and trade diversion effect; Brown and Crowley (2010) analyze the influence of anti-dumping of U.S. and the EU on China's export with significant trade deflection effect and indistinctive trade depression effect.

The above literature discusses the impact of anti-dumping from different aspects and provides significant reference for studies on anti-dumping. At present, although scholars have studied the influence of American anti-dumping towards China on China's export, however, the datas selected are relatively early and research on this aspect is still relatively small, and basically, it is from anti-dumping cases before and after anti-dumping investigation or anti-dumping complaint as anti-dumping period analysis. Differently, this paper is based on five-year time series data and actual anti-dumping duty value, and based on the 2 years before anti-dumping verdict, the year of the verdict, and 2 years after anti-dumping verdict, a total of 5 years as the analysis period to find the export data and verdict result to conduct empirical analysis. Therefore, the analysis of the impact of American anti-dumping towards China on China's export has an important practical 
significance on theoretical research and policy formulation of China. Finally, feasible strategies of China to deal with American anti-dumping are proposed from government, industrial association and enterprises based on China's national condition so as to provide reference for Sino-US trade and promote stable development of Sino-US economic and trade relations.

\section{Model Specification and Data Processing}

\subsection{Model Specification}

In order to study the influence of American anti-dumping towards China on China's export, this paper set testing model in equation (1).

$$
\begin{array}{r}
\text { Ln(import } \left.{ }_{i t}\right)=\alpha+\beta_{1} \operatorname{Ln}\left(\text { import }_{\mathrm{it}-1}\right)+\beta_{2} \text { LnGDP }_{1}+\beta_{3} \text { LnGDP }_{2}+\beta_{4} \text { LnRREE } \beta_{5} \text { Duty }_{\mathrm{t}}+\beta_{6} \text { Duty }_{\mathrm{t}+1}+ \\
\beta_{7} \text { Duty }_{\mathrm{t}+2}+\beta_{8} \mathrm{AFF}_{\mathrm{t}}+\beta_{9} \mathrm{AFF}_{\mathrm{t}+1}+\beta_{10} \mathrm{AFF}_{\mathrm{t}+2}+\beta_{11} \mathrm{NEG}_{\mathrm{t}}+\beta_{12} \mathrm{NEG}_{\mathrm{t}+1}+\beta_{13} \mathrm{NEG}_{\mathrm{t}+2}+\mathrm{u}_{\mathrm{it}}
\end{array}
$$

In equation (1), $i$ represents the $i_{\text {-th }}$ product involved, the product data involved are all data with the HS6-bit encoded segmentation, $t$ represents the time, in the empirical study, data of the two years before anti-dumping verdict of subdivided products involved, the year of anti-dumping verdict, and the two years after anti-dumping verdict are collected, which is $t=-2,-1,0,1$, 2 , where $t=0$ represents the year of anti-dumping verdict. In the regression, import ${ }_{i t}$ is used as the explained variable, and Ln(import ${ }_{\text {it }}$ ) represents the logarithmic value of HS6-bit encoded trade value of the involved products. Other variables are also defined in specific as follows.

Ln(import $\left.{ }_{i t-1}\right)$ is the logarithmic value of the trade value in the $t_{-1}$ year of products involved, in order to control the influence of trade value in previous years on Ln (import ${ }_{i t}$ ).

LnGDP $_{1}$ represents the logarithmic value of China's GDP over the years. The increase of a country's GDP will also affect exports. The higher the GDP, the greater the trade flow.

LnGDP $_{2}$ represents the logarithmic value of American GDP over the years. The higher the GDP, the greater the trade flow.

RREE represents the logarithmic value of the real effective exchange rate for RMB. The original sequence takes 2010 as the base year, with a value of 100. Other years use 2010 as the base year for conversion.

Duty is the anti-dumping duty rate, Duty , Duty $_{t+1}$, and Duty $y_{t+2}$ represent the impact of anti-dumping duties on China's exports of involved products to the United States to the year, first and second year of anti-dumping verdict, respectively. 0 is set in the year without duty.

AFF is a dummy variable for the affirmative verdict. When the verdict of a case is affirmative, the value is 1 , otherwise it is 0 . That is, when the verdict is affirmative, the year to the verdict of $A F F_{t}$ is set to 1 and the rest to 0 ; the first year after the verdict is $A F F_{t+1}$ with a value of 1 and the rest is 0 , the second year after the verdict is $A_{F F}+2$ with a value of 1 and the rest is 0 ; these three dummy variables examine the impact of affirmative verdict on China's exports to the United States.

NEG is the dummy variable of negative verdict, the setting of this dummy variable is the same as above AFF dummy variable. The difference is only to examine the impact of negative verdict on China's exports to the United States; $\mathrm{u}_{\mathrm{it}}$ is a random disturbance term.

\subsection{Data sources and processing}

The data of product involved in anti-dumping cases in this paper adopts the 6-bit subdivided product data under the HS (The Harmonized Commodity Description and Coding System). The anti-dumping data comes from the Global Antidumping Database, which contains the HS6-bit encoded data of the involved product, the verdict result of each case and the imposition of anti-dumping duty. Export data in five consecutive years for HS6-bit of each product involved has been obtained, including data of two years before, the year, and two years after the anti-dumping verdict. From 1995 to 2016, the United States launched a total of 141 anti-dumping lawsuits against China. The sample period of export data is from 1994 to 2017. The sample period of anti-dumping case is from 1995 to 2014, some cases with missing data eliminated, so there are 89 valid cases in the sample period, including 73 affirmative verdict and 16 negative verdict. Table 1 describes 
variable meaning and data sources of the model. Table 2 shows the descriptive statistics of related variables in model regression and the expected symbols of the regression results.

Table 1 Variable meaning and data sources

\begin{tabular}{|c|c|c|}
\hline variables & Meaning of variable & Data source \\
\hline import $_{\text {it }}$ & $\begin{array}{l}\text { The export value of products involved in } \\
\text { case i exported from China to the U.S. in } \\
\text { the } t_{\text {th }} \text { year. }\end{array}$ & $\begin{array}{l}\text { UN Comtrade Database. Due to differences in } \\
\text { trade data between China and the U.S., the U.S. } \\
\text { anti-dumping authorities will be more inclined to } \\
\text { adopt statistical data from U.S. Therefore, import } \\
\text { data of the U.S. from China is taken as export data } \\
\text { of China to the U.S. (unit: ten thousand USD) }\end{array}$ \\
\hline import $_{\text {it- } 1}$ & $\begin{array}{l}\text { The export value of products involved in } \\
\text { case i exported to the U.S in the t- } 1 \text { year. }\end{array}$ & $\begin{array}{l}\text { UN Comtrade Database. Import data of the U.S } \\
\text { from China is taken as export data of China to the } \\
\text { U.S. (unit: ten thousand USD) }\end{array}$ \\
\hline $\mathrm{GDP}_{1}$ & China's nominal GDP over the years & $\begin{array}{l}\text { World Economy, www.8pu.com } \\
\text { (unit: hundred million USD) }\end{array}$ \\
\hline $\mathrm{GDP}_{2}$ & The U.S nominal GDP over the years & World Economy (unit: hundred million USD) \\
\hline RREE & Real effective exchange rate for RMB & International Financial Statistics, IMF \\
\hline Duty & Anti-dumping duty & Global Antidumping Database \\
\hline AFF & Cases of affirmative verdict & Dummy variable \\
\hline NEG & Cases of negative verdict & Dummy variable \\
\hline
\end{tabular}

Table 2 Descriptive statistics of variables and expected symbols

\begin{tabular}{|c|c|c|c|c|c|}
\hline variable & Maximum & Minimum & Mean & $\begin{array}{l}\text { Standard } \\
\text { deviation }\end{array}$ & $\begin{array}{c}\text { Expected } \\
\text { symbols }\end{array}$ \\
\hline Ln(import $\left.{ }_{\text {it }}\right)$ & 12.920 & 0.200 & 8.294 & 2.113 & \\
\hline Ln(import $\left.{ }_{\text {it- } 1}\right)$ & 12.760 & 0.670 & 8.272 & 2.041 & + \\
\hline LnGDP $_{1}$ & 11.720 & 8.640 & 10.616 & 0.747 & + \\
\hline $\operatorname{LnGDP}_{2}$ & 12.170 & 11.200 & 11.843 & 0.187 & + \\
\hline LnRRER & 4.880 & 4.240 & 4.591 & 0.110 & - \\
\hline Duty & 386.280 & 0 & 25.682 & 69.026 & - \\
\hline AFF & 1 & 0 & 0.161 & 0.367 & - \\
\hline NEG & 1 & 0 & 0.039 & 0.195 & + \\
\hline
\end{tabular}

\section{Regression Results and Analysis}

According to equation (1), HS6-bit products involved are regressed, and Table 3 shows the results of regression. Models 1-3 are the regression results of equation (1), but key variables are not the same. Model 1 is the impact of imposing anti-dumping duties on export value of relevant products exported from China to the U.S., Model 2 shows the impact of affirmative verdict of anti-dumping cases on export value, and Model 3 is the impact of negative verdict on export value.

According to regression results in Table 3, the impact of each variable can be analyzed as below.

1) The impact of China's export over the years on China's current export to the United States. The China's Ln(import ${ }_{i t-1}$ ) sign is positive and both are significant at the $1 \%$ level, which shows that the export factors over the years have a significant positive impact on China's export to the United States in the current period, and have a positive effect, which is in line with expectations.

2) The impact of nominal GDP of China and the U.S. on China's export trade value. The regression coefficient of China's $\operatorname{LnGDP}_{1}$ is positive, indicating that the larger (smaller) the GDP, the larger (smaller) China's export trade value; the regression coefficient of the U.S. LnGDP $_{2}$ is negative, indicating that the larger the scale of U.S. GDP has a negative impact on China's export trade value, which is not in line with expectations, it shows that the U.S. anti-dumping towards China inhibits China's export of relevant involved products to the United States, the decrease of 
China's exports to the United States also promotes the increase in the production of the same products of local enterprises in the United States, then pull the increase in the U.S. GDP.

3) The impact of real effective exchange rate of RMB on China's export. When RMB depreciates against the US dollar, for the U.S., China's export products will be cheaper and China's exports will rise, which is also confirmed by regression results.

4) Anti-dumping duty. After the anti-dumping lawsuit is initiated, the U.S. Department of Commerce and U.S. International Trade Commission make affirmative verdict, then anti-dumping duty will be imposed on the case and the duration for imposition of anti-dumping duty is five years. Model 1 shows that anti-dumping duty has reduced the amount of China's exports to the year of the verdict and the first year after the verdict, and the impact on the second year is not significant.

5) Affirmative verdict. Model 2 shows that affirmative verdict has a negative impact on the export to the year of the verdict and the first year after the verdict, and the trade restriction effect on the export value to the year of anti-dumping verdict is greater than the first year after the verdict.

6) Negative verdict. According to the regression results in Model 3, it can be seen that the U.S. anti-dumping towards China and negative verdict reduced the amount of China's exports to the United States to the year of the verdict, it is not in line with expectations; but did not significantly reduce China's exports to the U.S in the first and second year after anti-dumping verdict.

Table 3 Regression results of the impact of U.S. anti-dumping towards China to China's export

\begin{tabular}{|c|c|c|c|}
\hline \multirow[t]{2}{*}{ Explanatory variables } & \multicolumn{3}{|c|}{ Explained variables: $\operatorname{Ln}\left(\right.$ import $\left._{\text {it }}\right)$} \\
\hline & Model 1 & Model 2 & Model 3 \\
\hline & $0.97012^{*}$ & 0.97493* & $0.97140 *$ \\
\hline Ln(import it-1 $\left._{1}\right)$ & (82.31822) & (83.71026) & (81.30674) \\
\hline & 0.06978 & 0.08428 & 0.09658 \\
\hline $\operatorname{LnGDP}_{1}$ & $(0.44426)$ & $(0.54183)$ & $(0.60078)$ \\
\hline & -0.09258 & -0.20160 & -0.22022 \\
\hline $\operatorname{LnGDP}_{2}$ & $(-0.17465)$ & $(-0.38310)$ & $(-0.40487)$ \\
\hline LnRRER & $\begin{array}{l}-0.91328 * * \\
(-2.28594)\end{array}$ & $\begin{array}{l}-0.85225^{* *} \\
(-2.16024)\end{array}$ & $\begin{array}{l}-0.95169 * * \\
(-2.29293)\end{array}$ \\
\hline Duty $_{t}$ & $\begin{array}{l}-0.00247^{*} \\
(-7.11074)\end{array}$ & & \\
\hline Duty $_{t+1}$ & $\begin{array}{l}-0.00046 \\
(-1.29771)\end{array}$ & & \\
\hline Duty $_{t+2}$ & $\begin{array}{l}0.00005 \\
(0.14186)\end{array}$ & & \\
\hline $\mathrm{AFF}_{\mathrm{t}}$ & & $\begin{array}{l}-0.51607 * \\
(-7.77097)\end{array}$ & \\
\hline $\mathrm{AFF}_{t+1}$ & & $\begin{array}{l}-0.05156 \\
(-0.76685)\end{array}$ & \\
\hline $\mathrm{AFF}_{\mathrm{t}+2}$ & & $\begin{array}{l}0.04382 \\
(0.64344)\end{array}$ & \\
\hline $\mathrm{NEG}_{\mathrm{t}}$ & & & $\begin{array}{l}-0.20226 * * * \\
(-1.63989)\end{array}$ \\
\hline $\mathrm{NEG}_{\mathrm{t}+1}$ & & & $\begin{array}{l}0.09400 \\
(0.75951)\end{array}$ \\
\hline $\mathrm{NEG}_{\mathrm{t}+2}$ & & & 0.20221 \\
\hline $\mathrm{C}$ & $\begin{array}{l}4.89087 \\
(0.87445)\end{array}$ & $\begin{array}{l}5.71842 \\
(1.03052)\end{array}$ & $\begin{array}{l}6.20613 \\
(1.07855)\end{array}$ \\
\hline $\mathrm{R}^{2}$ & 0.880 & 0.882 & 0.875 \\
\hline DW stat & 2.183 & 2.181 & 2.170 \\
\hline F-statistic & 1030.726 & 1047.942 & 978.156 \\
\hline Number of observations & 990 & 990 & 990 \\
\hline
\end{tabular}

Note: In the Table 3,() is the t-statistic, *, **, *** denotes the significance level of $1 \%, 5 \%$, and $10 \%$, respectively. 


\section{Conclusion and Policy Suggestions}

This paper adopts the case data of the U.S. anti-dumping towards China from 1995 to 2014 to study the impact of the U.S. anti-dumping on China's export. The results show that anti-dumping duty, anti-dumping affirmative verdict, and negative verdict all have an inhibiting effect on China's exports, among them, anti-dumping duty and affirmative verdict have the greatest negative impact on China's exports to the United States to the year of the verdict, which are significant at the $1 \%$ level; the negative verdict has a negative impact on China's exports to the year of the verdict, which is significant at the $10 \%$ level, one regression coefficient of negative verdict is negative and two are positive, and compared with affirmative verdict, the trade effect is greatly reduced.

Faced with the U.S. anti-dumping towards China, Chinese government, industrial association and enterprises are required to fully recognize the seriousness of anti-dumping, take appropriate strategies to deal with trade conflicts on anti-dumping in Sino-US import and export trade. Government shall strengthen the guidance on operational activities of export enterprises to the U.S., provide the consulting services of related laws and regulations, organize targeted training on responding to lawsuits, let enterprises know procedures of responding to lawsuits more deeply; industrial association shall focus on the cultivation of professional talents, coordinate export self-discipline of enterprises, help enterprises respond to lawsuits; enterprises shall actively respond to lawsuits, strive for settle duty-free lawsuits, enhance core competitiveness, fully understand the U.S. anti-dumping laws and regulations, and protect self-interest to minimize trade frictions of anti-dumping on Sino-US trade and loss of China's economic interests.

\section{References}

[1] Yang Shihui, Wang Hongling, Shu Yanyan., Anti-dumping Dynamic Game and Its Effect Analysis [J]. Systems Engineering-Theory \& Practice, 2001, (11).

[2] Yang Zhansheng, Ma Haiyan, Zhong Changbiao., Empirical Analysis on the Reasons of USA's Anti-dumping towards China [J]. Science \& Technology and Economy, 2014, (4).

[3] Xie Jianguo, Huang Qiuyue., Antidumping and China's Export Damage: An Empirical Study based on US-China Antidumping data [J]. World Economy Studies, 2014, (2).

[4] Tang Yihong, Zhang Pengyang., An Empirical Study on the Long-term and Short-term Effects of Anti-dumping on Export: Based on Difference-in-Difference Model [J]. World Economy Studies, 2016, (11).

[5] Wang Jingyi., Exploration on Trade Effect of Anti-dumping Investigations on China- Based on Case Analysis of Anti-dumping Investigation of the UN on China's Photovoltaic Products [J]. Price Theory and Practice, 2014 (12): 115-117.

[6] Wang Xiaosong, Zhai Guangyu, Lin Faqin., Exploration on Inhibiting Effect of Anti-dumping on China's Export [J]. The Journal of World Economy, 2015, (5).

[7] Khatibi A., The Trade Effects of European Antidumping Policy [R]. ECIPE Working Paper NO. 07/2009.

[8] Vandenbussche H., M. Zanardi., The Chilling Trade Effects of Antidumping Proliferation [J]. European Economic Review. 2010, 54 (6):760-777.

[9] Besedeš T., T. J. Prusa., Antidumping and the Death of Trade[R]. National Bureau of Economic Research, 2013.

[10] Avsar V., Antidumping, Retaliation Threats, and Export Prices. World Bank Economic Review [J]. 2013, 27 (1):133-148

[11] Soonchan P. The Trade Depressing and Trade Diversion Effects of Antidumping Actions: the Case of China [J]. China Economic Review, 2009, 20(3):542-548

[12] Bown C. P., M. A. Crowley., China's Export Growth and the China Safeguard: Threats to the World Trading System [J]. Canadian Journal of Economics. 2010, 43 (4):1353-1388 